\title{
The Trilogy of the Academic History of Islamic Studies in China
}

\author{
Alimu Tuoheti \\ Frontier Research Institute for Interdisciplinary Sciences, Tohoku University, Sendai, Japan \\ Email address: \\ tuoheti.alimu@orinst.ox.ac.uk

\section{To cite this article:} \\ Alimu Tuoheti. The Trilogy of the Academic History of Islamic Studies in China. International Journal of Philosophy. \\ Vol. 9, No. 2, 2021, pp. 85-89. doi: 10.11648/j.ijp.20210902.12
}

Received: March 26, 2021; Accepted: May 1, 2021; Published: May 8, 2021

\begin{abstract}
The field of academic history of the study of Islam and Muslims in China consists of Anglo-American, that is, English literature; Japanese literature, European literature, mostly French, Russian, and German; and Chinese literature, divided by geographical and linguistic boundaries, in which Author has published own works in English, Chinese and Japanese (History of Islamic Studies in Japan-Volume on China, Islam in China: A History of European and American Scholarship, History of Islamic Studies in China.) The author calls these three books the trilogy of the academic history of Islamic Studies in China. In this Trilogy, Author explores the development of different regions and countries academic history of Chinese Islamic studies, which has gone through a bumpy and tortuous historical process. Each stage has its own unique characteristics in terms of social ideological background, ways of representation and research findings. This paper sheds light on the understanding of the development process of academic research and the characteristics of various periods of the field of academic history of the study of Islam and Muslims in China. It also provides some reference for the history of the development of Sino-foreign relations, the history of cultural exchanges, and other related topics. Especially the international trend shows the importance of this research field.
\end{abstract}

Keywords: Japan, European and American, China, Chinese Islam, Muslim, Academic History, Academic Value

\section{Introduction}

The study of Chinese Islam and Muslim in the World has become more and more prosperous however, there is little understanding of these works in the World research community. In addition, we should also see that the study of Chinses Islam is still in a relatively marginal position in the world academic circle, which is very weak compared with the developed Chinese study or Islamic world study, which is obviously not conducive to academic exchanges and the further development of Chinese Islamic research. Chinese Islam and culture are a part of the world's Islam and culture. on the other hand, they are part of Chinese culture. Chinese Muslims are also dividing into Uyghur, Kazak of Turkic language family, and Hui of Chinese language family. It is of great significance to understand Chinese Islam. According to the perspective of academic history, there have been many research results in this area. The World academic circle should pay attention to and think about these characteristics of the Studies of the Chinses Islam and Muslim, draw lessons from, reflect on and criticize their research methods and achievements, open up the thinking of the study of the Chinses Islam, and promote the study of the Chinses Islam.

The field of academic history of the study of Islam and Muslims in China consists of Anglo-American, that is, English literature; Japanese literature, European literature, mostly French, Russian, and German; and Chinese literature, divided by geographical and linguistic boundaries, the studies of Chinese Islam by worldwide academic society are consisted of two schools, "western" and "Japanese". It also includes China's research on Chinese Islam and Muslim. The author will focus my research "The studies of Chinese Islam by Japanese Academic Society", "The studies of Chinese Islam by European and American Academic Society" and "The studies of Chinese Islam by Chinese Academic Society".

About the study on Chinese Islam, Author have collected and obtained most of the materials concerning the achievements of Japanese, European, American, Chinese study. 1 finished and published the research project on:

History of Islamic Studies in Japan-Volume on China 
Islam in China: A History of European and American Scholarship

History of Islamic Studies in China

The author called the three books: "The Trilogy of the Academic History of Islamic Studies in China", it is introduced in this article.

\section{History of Islamic Studies in Japan-Volume on China}

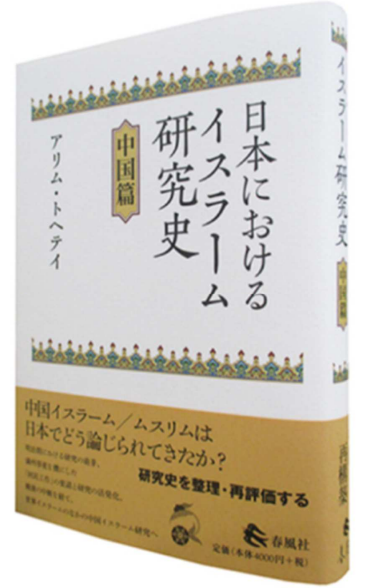

Figure 1. Alimu Tuoheti, History of Islamic Studies in Japan-Volume on China, Shumpusha Publishing, 2018, 310 pages.

Before the Meiji period, there was no Japanese research on Islam in China or Chinese Muslims. Since then, a modernizing Japan established a new relationship with the Qingrulers. At that time, the Hui Muslims were revolting against the government and rebellions took place one after another. However, the Japanese academia was not aware of this. According to the Japanese scholars, Endo Sasaki's articles were the earliest one on Islam in China, published respectively in 1911 and 1912. Since then, there were more and more researches on Islam in China, in both the history of cultural exchange between China and Europe, and religious history. Kowata Rokurou was one of the outstanding scholars concerning Islam in China. He published "Huiru Intellectuals in Late Ming and Early Qing" introducing a great number of 'Huiru scholars' life and works. There were also other research communities. Some were Japanese Muslims who converted in China and conducted research on Islam. One typical case is Tanaka Ieppei with his remarkable works. At the same time, there were also another group of people, who did "research" for the Japanese government, which was getting ready to invade the mainland of China. There were several institutions for such research.

The most important period comes when Japan invaded China, 1930-1945. Since the 1930s, especially after the incident of 1931 and the founding of "Manchuguo," the Japanese administration was in close contact with the Muslims in northeastern and northern China. Coping with such a situation became an urgent issue. Therefore, the Japanese government realized the importance of studying Islam in
China, and set up institutes such as the "Association of Islamic Culture" and the "Study Center for the Islamic World" (later became "the Institute for the Islamic World") to conduct research on Islam and the Islamic world. They also created several journals, such as ISURAMU (Islamic Culture), KAIKTO SEKAI (The World of Islamic) and KAIKYO-KEN (Issues on Islam), a quarterly for the Japanese Ministry of Foreign Affairs. As for research, there were the Committee for Ethnic Inquiries in Eastern Asia, the National Ethnic Studies Institute and other departments conducting field research in China. Their achievements were very fruitful. Apart from the public institutes, there were also independent scholars with their rich research findings. At that time, the Japanese government generously invested upon such studies, so that official and academic researchers began to merge into one. Studies done by the Japanese Muslims who converted in China was used by the Japanese government for invasion purposes. This is a unique phenomenon. Originally there was no research on Islam in Japan, let alone Chinese Muslims. Therefore, translation of Chinese, European and America works into Japanese was necessary. Tasaka Kodo was one of the outstanding scholars on philology. His Propagation of Islam in China was a monumental work.

The Second World War ended with the defeat of Japan. Thus, Islamic studies entered another era, with changes in the identity of researchers and the nature of their researches. The research institutes set up during the war were either dissolved or merged into other institutions. The researchers themselves also lost their resources. Things were especially hard for the field researchers, for they were deprived of their opportunities to go to north Asia, central Asia and the northwestern part of China. Therefore, many of them changed their research orientation. There were also some scholars who left the field altogether. We can say that after the war, studies on Islam in China were interrupted. At the same time, however, several scholars insisted on continuing their research. Thanks to their persistent endeavor, Islamic studies in China could also borrow from the latest academic achievements. Although the number of new researchers was still small, the community of Islamic studies in Japan was still growing. Due to the lack of field work, there were no such documents. Talking from an academic point of view, one of the changes is that the focus shifted to the analysis of social history, Hui revolts and Sufism, etc.

There is a new revival of studies of Islam in China in the recent 30 years. For example, the Middle East Research Association was established. By Organized a 3-year project in 1988, sponsored by the Ministry of Education, Science, Sports and Culture. It focuses on the cosmopolitan life style in the Islamic world, including China, with a special concern for the Muslim question. In 1997, sponsored by the same Ministry, a 5-year program of "Islamic Regional Studies" was set up. The most noticeable event was the founding of School Departments of Regional Research in the Islamic world, in Kyoto University and Tohoku University. The most important trait was that Islam and Muslims in China were taken as part of world Islamic regional culture. This is very different from 
the research goals before the war. The research focus now is: historical studies of the Yuan and Ming, the Hui revolts in the Qing Dynasty, the Sufi schools, and various policies towards Islam adopted by the Chinese Communist Party, the social situation of the Hui, and other historical studies. Also, there are other aspects, such as regional ethnology, sociology, anthropology, as well as the "Huiru" in the background of culture, philosophy, history of ideas, and so on.

Finally, Author will give a conclusion of the characteristics of the studies of Islam and Muslims in China conducted by the Japanese scholars, and give a more detailed analysis.

Author have listed four stages of the development. There are representative figures, academic achievements, and different traits for each stage. Author's research will give detailed comments, so that the Chinese academia may have a fuller understanding of the development of the studies of Islam and Muslims in China conducted by the Japanese scholars, including research orientation, foci, traits, and so on. It will be a useful reference for the history of the relationship between China and Japan, of cultural exchange, and the development of Japanese scholarship. After understanding these issues, one could see the Japanese political society better from a more profound perspective, and get some knowledge of the religious psychology and thinking pattern of the modern Japanese people. [1-8]

\section{Islam in China: A History of European and American Scholarship}

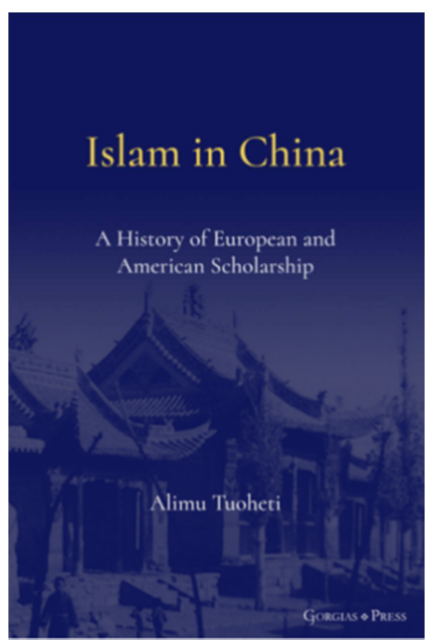

Figure 2. Alimu Tuoheti, Islam in China: A History of European and American Scholarship, Gorgias Press, 2021, 234 pages.

Western studies on Islam and Muslims in Mainland China can be divided into two parts according to geographical and linguistic boundaries: (1) Research in British and American, written in English; (2) The European continent, mainly the research written in French, Russian, and German. Regarding the collection of academic achievements in these aspects and the staging of Western Islamic studies, the main purpose of Author's research is to comment on the key academic achievements in each period. This research mainly deals with the study of Islamic Chinese literature. Generally speaking, foreign scholarly research on Islam and Muslims in Mainland China clearly includes the Uyghur and other Turkic languages and the Hui nationality in Chinese. Due to the differences in history, language and culture of these nationalities, inevitable variations occur in research results and methods. The study of Chinese Islam in Western academic circles can be roughly divided into four stages, which will be discussed in chronological order and its characteristics.

Grounded on the previous achievements, Author divide the historical process of the study on Chinese Islam into four major periods: initial period (before the $20^{\text {th }}$ century), empirical period (the $20^{\text {th }}$ century-1949), the period of the new China including the cold-war (1949-2000), and the period after the opening-up (2000- today). In each period, scholars and their works constitute special characteristics of their times, which often shines light on the changing international situation. This research plan aims mainly to collect western achievements in research on Chinese Islam as many as possible, and to systematically sort the data and clearly introduce them.

In the $19^{\text {th }}$ century, the development of natural science and the emergence of enlightenment gradually gave birth to social science in modern Europe. As Europe opened the door to China in the middle of the $19^{\text {th }}$ century, Western academia began to pay attention to China, and Western theories and methods progressively entered China and were accepted by Chinese scholars. Most saliently, some Christian missionaries and Orientalists have completed more serious studies of Islam in China, and published several corresponding works and research results on this basis. During this period, those who studied Islam and Muslims in China could be divided into two categories. (1) Religious people, including Christian missionaries. (2) Scholars, including Orientalists. Subsequently, when Western missionaries entered China, they found the presence of a large Muslim group, so they began to study them and organize missionary work. Although this missionary activity proved unsuccessful in terms of the number of converts to Christianity, it maintains a certain positive significance regarding religious and cultural exchange, and cross-civilizational interaction. Documents recording the encounters between Christianity and Islam in China since modern times are scattered in journals such as Chinese Repository, The Chinese Recorder, Friends of Moslems, The Moslem World and China's Millions. In the $20^{\text {th }}$ century, the study of Islam and Muslims in Mainland China by Anglo-American missionaries reached its peak. The main characteristics of this period are as follows: (1) The establishment of important academic journals and their research. (2) The establishment of various structures and publication of the first important research works. this period, Western scholars collected and studied Islamic books and documents in Chinese and published some bibliographies and introductions. These research results, firstly, from a historical point of view, mainly include the relationship between Mainland Chinese and Arab, Persian, Turkic, and other Islamic regions and ethnic groups; the earliest Muslims to the 
mainland; Chinese and Arabid inscriptions; the late Qing Dynasty Yunnan and Northwest Hui uprising and the meaning of Hui. Second, from the perspective of the current situation, they involve a visit to a mosque, population estimation, social and religious conditions, and how to preach the gospel to Muslims. The significance of these monographs is that they are the first important works about Islam in China written by Westerners. In the process of writing, they possess common characteristics. Since the 2000's, the study of Chinese Islam and Muslim in the West has become more and more prosperous, according to the perspective of academic history, there have been many research results in this area. mainly from "Research opportunities under the background", "About 'Muslim Confucian' studies", “Academic works based on field work", "Research in the political field", "Research on religion, ethnicity, and Culture" topics for research. The carding and analysis of these research results is conductive to the development of the world's research on Chinese Islam.

In this book, Author explore the development of academic history of Chinese Islamic studies, which has gone through a bumpy and tortuous historical process. Each stage has its own unique characteristics in terms of social ideological background, ways of representation and research findings. This paper sheds light on the understanding of the development process of academic research and the characteristics of various periods of the field of academic history of the study of Islam and Muslims in China. It also provides some reference for the history of the development of Sino-foreign relations, the history of cultural exchanges, and other related topics. Meanwhile, as a Uyghur scholar, Author is intent to explore the history of own ethnicity and religious culture, and to give assessment and critics, which in turn will offer some reference to the western and Japanese scholars. [9-14]

\section{The Studies of World and Chinese Islam by Chinese Academic Society}

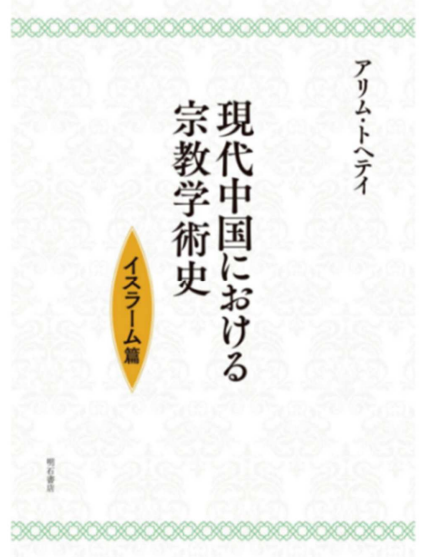

Figure 3. Alimu Tuoheti, History of Islamic Studies in China, Akashi Publishing, August 2019, 295pages.

In the subject, the author divides the development and evolution process of Chinese Islamic academic history into "Background", "People, Institutions and Academic journals", "Academic conference", "Reference books and historical data collation", "Research in the field of History", "Research in the field of Religion and Philosophy", "research in the field of Politics and Society", "Research in the field of Literature and Art" And other areas of research. The general characteristics of the study of academic history can be summarized as follows:

1. The definition of the research object: Islam was introduced into China from the Arab and Central Asian regions in the middle of the 7 th century. Due to the different time, social and historical environment and cultural background of various ethnic regions, Islam and its ethnic groups of Chinese (Hui, etc.) and Turkic (Uyghur, Kazak, etc.) were formed in the process of dissemination, development and evolution Culture is divided into two systems: Islam with national characteristics. Today, as one of the five major religions in China, Chinese Islam, as a national and regional religion, has a certain historical influence and formed the style of the Chinese nation. Due to the different characteristics of various nationalities and regions, different research methods are used to discuss.

2. The academic history of Islam in China. It not only refers to the academic history of Chinese scholars' research on Chinese Islam, but also includes the carding of various researches and achievements of Chinese scholars on foreign Islam and Muslims. This includes the study of Islamic classics such as Koran and hadith, history, pedagogy, philosophy, politics, society and culture. Islam and Muslims in different regions of foreign countries also have different characteristics, and the research methods also respect this aspect of attention.

3. On the origin of academic history: according to the author's own and previous research results, it can be concluded that academic research with contemporary significance began at the beginning of the 20th century. Under the background of the introduction of Western learning to the East, modern academic research methods also affected the research field of Islam in China. There are four imams with high academic level, such as Ha Decheng, Wang Jingzhai, Da Pusheng and Ma Songtin. There are also Chen Hanzhang, Chen Yuan and Chuan Tongxian non-Muslim scholars joining the ranks of Islamic researchers. There was little research before the 20th century.

4. The year 2000 can be regarded as the dividing line in the evolution of modern Islamic academic history. The period from the beginning of the 20th century to the founding of new China can be regarded as the beginning period. The period from the founding of new China to the reform and development can be regarded as the initial period. During this period, due to various political movements and other reasons, China's Islamic academic history and many other fields suffered setbacks such as stagnation to varying degrees. The period from reform 
and development to 2000 can be regarded as the prosperous period of Islamic academic research in contemporary China. Islam research is not only a religious research task, but also a cultural phenomenon, from the political, social, economic and even information science perspective. During the period from 2001 to now, the subject consciousness is clear and the research methods are diversified. Many industries and scholars have actively participated in this research field, that is, using the theories and methods of religion, ethnology, anthropology, sociology, history, philosophy, linguistics, culture, politics and other disciplines to systematically study the historical, political, economic, cultural and other phenomena of Islam and Muslims, so as to lay a foundation for the further development of China's Islamic research This is the foundation. [15]

\section{Conclusion}

The field of academic history of the study of Islam and Muslims in China consists of Anglo-American, that is, English literature; Japanese literature, European literature, mostly French, Russian, and German; and Chinese literature, divided by geographical and linguistic boundaries, in which Author has published his works in English, Chinese and Japanese. In this paper, author explores the development of academic history of Chinese Islamic studies, which has gone through a bumpy and tortuous historical process. Each stage has its own unique characteristics in terms of social ideological background, ways of representation and research findings. This paper sheds light on the understanding of the development process of academic research and the characteristics of various periods of the field of academic history of the study of Islam and Muslims in China. It also provides some reference for the history of the development of Sino-foreign relations, the history of cultural exchanges, and other related topics.

\section{References}

[1] Alimu Tuoheti, History of Islamic Studies in Japan-Volume on China, Shumpusha Publishing, 2018, 310 pages.

[2] Alimu Tuoheti, A study of "Islam-Confucianism studies" in Japan, Social Sciences in Ningxia, Vol. 6, 2013, pp. 88-94.
[3] Alimu Tuoheti, A study of Islam in China during Japan's invasion of China, Journal of The Beifang University Of Nationalities, Vol. 6, 2014, pp. 38-40.

[4] Alimu Tuoheti, The academic history of Chinese Islamic Studies in Japan, Journal of Hui Muslim Minority Studies, Vol. 3, 2017, pp. 65-69.

[5] Alimu Tuoheti, A study of first Japanese Muslims and their research activities, Journal of religous studies, Vol. 92, 2019, pp. 400-401.

[6] Alimu Tuoheti "A Renewed Perspective on the History of Chinese Islamic Studies in Japan and Relevant Research Characteristics", The European Conference on the Social Sciences Conference Proceedings, 2019, pp. 63-72.

[7] Alimu Tuoheti, constructing a System of Collecting and Studying Source Material for Islamic Area Studies: Focus on A Renewed Perspective on the History of Chinese Islamic Studies in Japan, International Journal of Liberal Arts and Social Science, Vol. 8 (11), 2020, pp. 40-52.

[8] Alimu Tuoheti, THE HISTORY OF CHINESE ISLAMIC STUDIES IN JAPAN, pp. 173-185. (in Alimu Tuoheti, Islam in China: A History of European and American Scholarship, Gorgias Press, 2021, 234 pages.)

[9] Alimu Tuoheti, Research and Topics related on the Studies of Chinese Islam by Europe and America Academic Society, International Journal of Liberal Arts and Social Science, Vol. 8 (7), 2020, pp. 31-41.

[10] Alimu Tuoheti, The Characteristics of Academic History on the Studies of Chinese Islam by Western Academic Circles, Annals of Language and Literature, Vol. 4 (4), 2020, pp. 24-32.

[11] Alimu Tuoheti, The Studies of Islamic Areas by European and American Academic Society - Centered on Mainland China (The First Half of the 20th Century), American Journal of Humanities and Social Science (AJHSS), Vol. 7 (1), 2020, pp. $1-37$.

[12] Alimu Tuoheti, Islam in China: A History of European and American Scholarship, Gorgias Press, 2021, 234 pages.

[13] Alimu Tuoheti, HISTORICAL STUDIES OF CHINESE ISLAM IN WESTERN ACADEMIC CIRCLES pp. 165-172. (in Alimu Tuoheti, Islam in China: A History of European and American Scholarship, Gorgias Press, 2021, 234 pages.)

[14] Alimu Tuoheti, Islam in China--A History of European and American Scholarship (The 21th Century), History Research Vol. 9 (1), 2021, pp. 39-48.

[15] Alimu Tuoheti, History of Islamic Studies in China, Akashi Publishing, 2019, 295 pages. 